\title{
Payback Period and Life Cycle Emissions of a Commercial Solar Carport with a Virtual Case Study
}

\author{
Kameswara Satya Prakash Oruganti ${ }^{1}$, Chockalingam Aravind Vaithilingam ${ }^{1,}$, Agileswari \\ Ramasamy $^{2}$, and Gowthamraj Rajendran ${ }^{1}$ \\ ${ }^{1}$ School of Engineering, Faculty of Innovation and Technology, Taylor's University Lakeside \\ Campus, No. I, Jalan Taylor's, Subang Jaya 47500, Selangor, Malaysia \\ ${ }^{2}$ Institute of Power Engineering (IPE), Universiti Tenaga Nasional, Kajang 43000, Selangor, Malaysia
}

\begin{abstract}
The solar carport is a significant technology-oriented infrastructural concept for facilitating electric vehicle charging stations (EVCS). The EVCS predominantly utilise the onsite solar photovoltaic energy for the charging of EVs. Moreover, EVCS can act as multipurpose $\mathrm{CS}$ to enable Grid to Vehicle (G2V) and Vehicle to Grid(V2G). Photovoltaic Electric vehicle charging station (PEVCS) can feed both EVs, traditional consumer loads, and can also feed power to the grid. Thus, enabling PEVCs across the various organisations and institutions can meet the local as well as dynamic demands incurred during charging of EVs. In this paper, a detailed economic and system analysis for the PEVCS is carried out using PVSyst and Helioscope for the area planning and shadow analysis. The normalised results of PEVCS is analysed along with the payback period and life cycle emissions are calculated for a virtual case study in Taylor's University. At the end of the $25^{\text {th }}$ year, based on the analysis, the overall payback and revenue for 25 years is $2,653.6$ kMYR will be generated by selling energy at $0.58 \mathrm{MYR} / \mathrm{kWh}$.
\end{abstract}

\section{Introduction}

Carbon dioxide $\left(\mathrm{CO}_{2}\right)$ emissions are increasing day by day from various sectors but majorly contributed by transport sector and electricity sector. So, adapting to electric vehicles (EVs) without having renewable energy-powered charging stations (CS) will again lead to a rise in emission levels [1]. On the other hand, EVs are more suitable for energy conservation, environmental protection and much efficient than fossil fuel-based vehicles [2]. It is noticed that [3] around $18.1 \%$ of the people are ready to shift towards EVs, but due to lack of an abundant number of CS, they are in a huge dilemma. This reason alone acts as a significant hurdle to adopt EVs [4]. So, this hurdle can be solved only by deploying a many number of CS even powered by renewable energy sources like solar, wind and fuel cells [5].

\footnotetext{
* Corresponding author: chockalingamaravind.vaithilingam@taylors.edu.my
} 
The construction of CS involves a lot of capital investment with viable payback period. Concerned party of private investors or government can induce various schemes like encouraging to charge at night for free, financial incentives for the EV purchasers, and infrastructure investors [6]. The authors from [7] had worked on the idea of utilisation of the existing gas stations and office premises will solve the anxiety problem of the EV users and also initial investment would reduce considerably as well as the penetration of EVs and renewable energy into the grid will be smooth [8,9].

The charging stations have classified into three types such as level 1 (slow) charging stations, level 2 (medium) charging stations, and DC fast-charging stations [10,11]. Lot of works were carried out for the technical aspects of the renewable energy based EV CS [1219], economic studies [20 - 27] were also conducted and very few studies[16], [22], [24], $[28,29]$ were discussed on the coupling of solar PV-Grid-Battery-EV systems.

The following sections of the manuscript is devised into two types, one is system analysis and the other is economic analysis, by anlysing the two sections the results of the sections can act as basis for calculation of payback period, total revenue generation, and life cycle emissions solar carport.

\section{System Analysis}

The system is represented by PV array, Grid-connected inverter and DC fast chargers to charge EVs is shown in Figure 1. The proposed system can cater two process namely EV charging and ancillary services. The layout of the solar carport is shown in Figure 2 is designed at $280 \mathrm{kWp}$ and installed virtually by utilizing the power of helioscope tool.

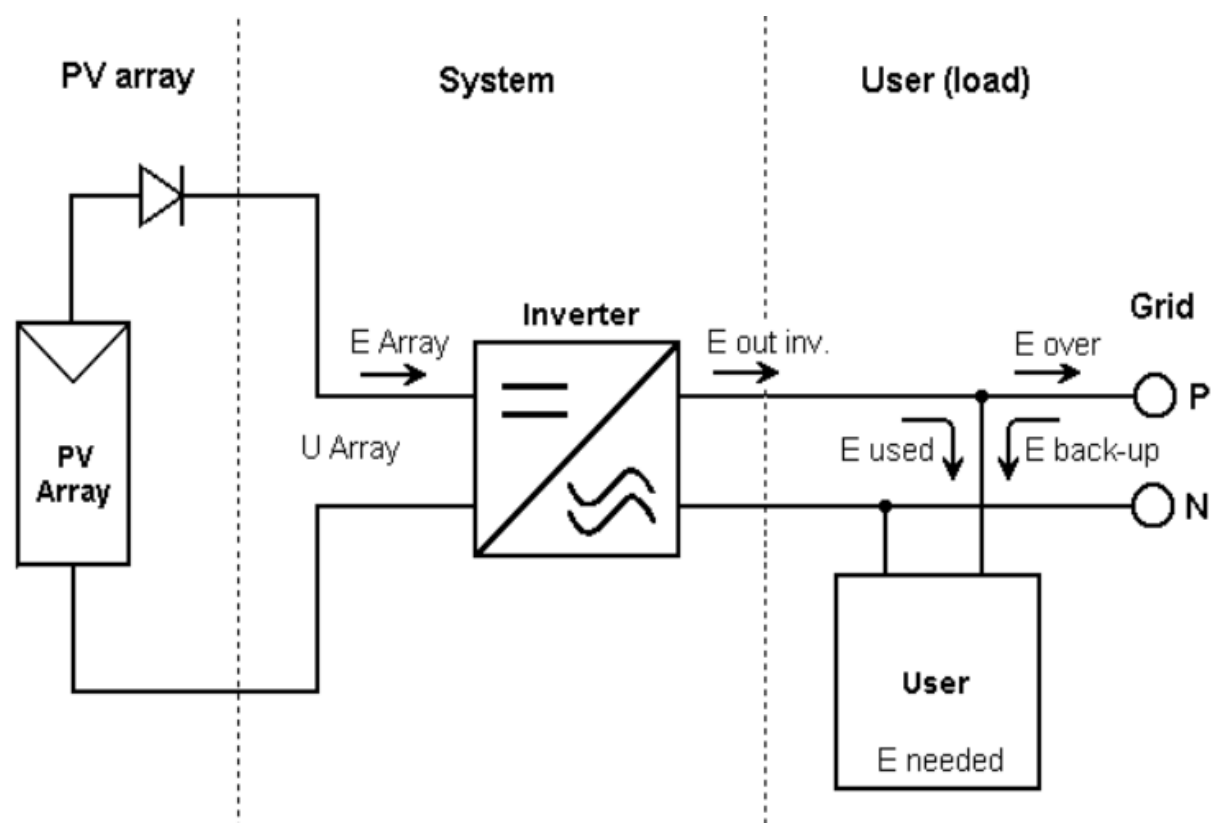

Fig.1. Simplified schematic of PEVCS 


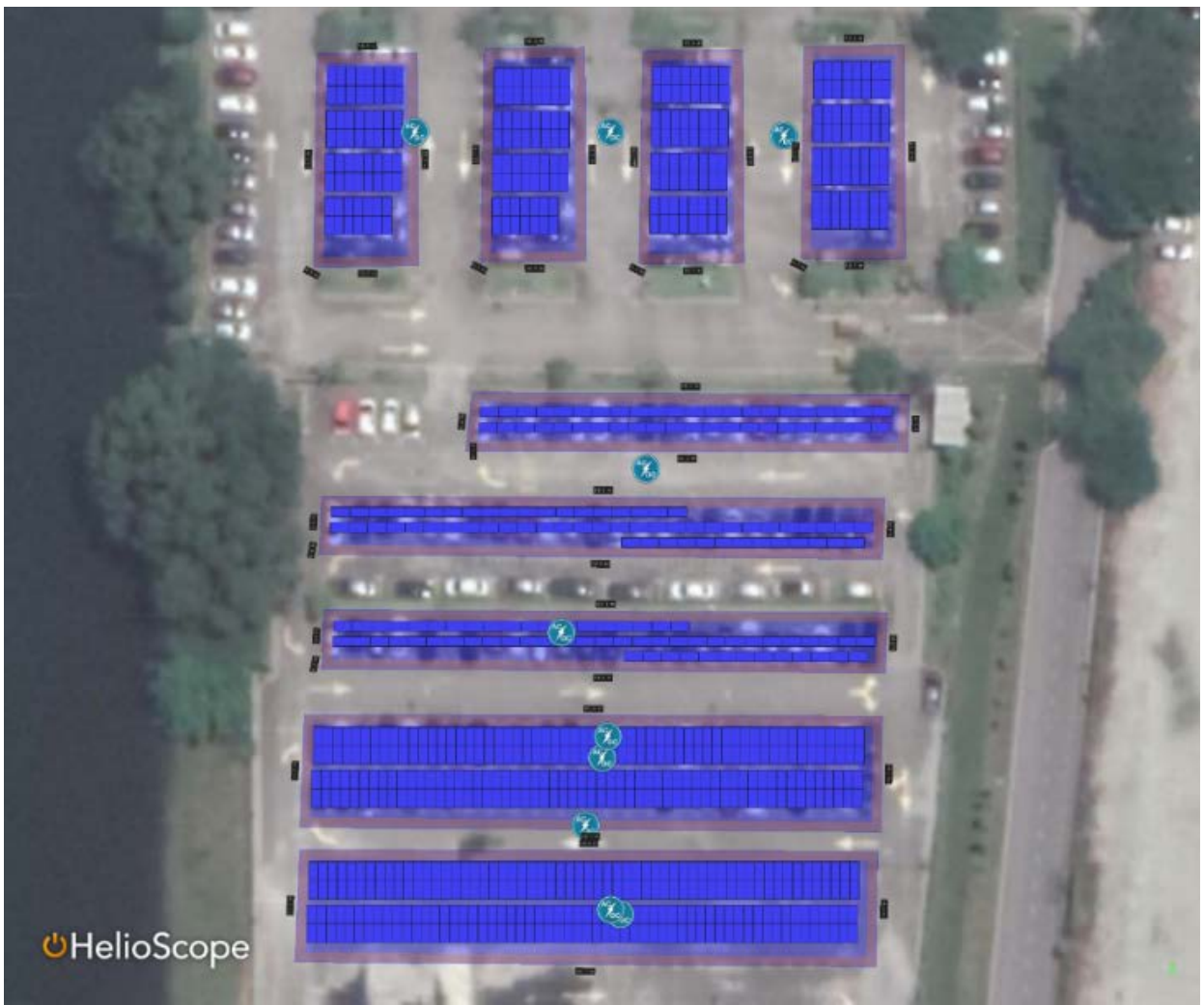

Fig.2. Layout of the proposed SPEVCS

The PEVCS can act as a distributed energy generation unit which can deploy or mount at various locations like workplaces, community grounds, universities etc. the generated output power can utilises to charge an EVs or it can be used to feed the grid as ancillary service. The virtual case study comprises of $280 \mathrm{kWp}$ PECS. The energy supplied from the PEVCS will be able to cater $6675 \mathrm{~km}$ drive equivalent of charge [30]. The normalised performance coefficients of the system are given in table 1 and shown in Figure 3. The annual reference incident energy in the collector plane is $4.38 \mathrm{kWh} / \mathrm{m}^{2}$.day and array production of $3.67 \mathrm{kWh} / \mathrm{kWp} /$ day with the losses of 0.054 produces $3.62 \mathrm{kWh} / \mathrm{kWp} /$ day. The total system losses are shown in the loss diagram in Figure 4. In that, the annual energy generated is $369.5 \mathrm{MWh}$ with a significant loss of $8.3 \%$ due to the increase in module temperature, followed by a $3.7 \%$ loss due to Incident angle modification (IAM). Figure 5 shows the daily input and output curve for a stipulated day in the entire synthetic simulation period. Figure 6 shows the amount of energy injected into the grid for the whole year. Figure 7 represents the comparisons between the energy injected to the grid and the effective energy at the output of an array. 
Table 1: Normalized performance coefficients

\begin{tabular}{|c|c|c|c|c|c|c|c|}
\hline & $\begin{array}{c}\text { Reference } \\
\text { incident } \\
\text { energy in } \\
\text { collector } \\
\text { plane }\end{array}$ & $\begin{array}{c}\text { Normalis } \\
\text { ed array } \\
\text { producti } \\
\text { on }\end{array}$ & $\begin{array}{l}\text { Normal } \\
\text { ised } \\
\text { system } \\
\text { losses }\end{array}$ & $\begin{array}{l}\text { Normalised } \\
\text { system } \\
\text { production }\end{array}$ & $\begin{array}{c}\text { Array } \\
\text { loss/incid } \\
\text { ent } \\
\text { energy } \\
\text { ratio } \\
\end{array}$ & $\begin{array}{c}\text { system } \\
\text { loss / } \\
\text { Inciden } \\
\text { t energy } \\
\text { ratio }\end{array}$ & $\begin{array}{c}\text { Perfo } \\
\text { rman } \\
\text { ce } \\
\text { ratio }\end{array}$ \\
\hline & $\begin{array}{c}\mathrm{kWh} / \mathrm{m}^{2} \text {. } \\
\text { day }\end{array}$ & $\begin{array}{c}\text { kWh/kW } \\
\text { p/day }\end{array}$ & & $\begin{array}{c}\mathbf{k W h} / \mathbf{k W p} / \\
\text { day }\end{array}$ & & & \\
\hline January & 4.25 & 3.56 & 0.052 & 3.51 & 0.161 & 0.012 & 0.827 \\
\hline February & 4.75 & 3.96 & 0.06 & 3.9 & 0.165 & 0.013 & 0.822 \\
\hline March & 4.87 & 4.05 & 0.062 & 3.99 & 0.168 & 0.013 & 0.82 \\
\hline April & 4.65 & 3.89 & 0.058 & 3.84 & 0.162 & 0.012 & 0.825 \\
\hline May & 4.54 & 3.79 & 0.056 & 3.73 & 0.165 & 0.012 & 0.823 \\
\hline June & 4.29 & 3.61 & 0.052 & 3.56 & 0.159 & 0.012 & 0.829 \\
\hline July & 4.24 & 3.55 & 0.053 & 3.5 & 0.162 & 0.013 & 0.825 \\
\hline August & 4.28 & 3.6 & 0.053 & 3.54 & 0.159 & 0.012 & 0.829 \\
\hline September & 4.37 & 3.67 & 0.055 & 3.61 & 0.161 & 0.013 & 0.827 \\
\hline October & 4.4 & 3.69 & 0.055 & 3.64 & 0.161 & 0.013 & 0.826 \\
\hline November & 4.06 & 3.44 & 0.049 & 3.39 & 0.153 & 0.012 & 0.835 \\
\hline December & 3.91 & 3.29 & 0.048 & 3.24 & 0.159 & 0.012 & 0.829 \\
\hline Year & 4.38 & 3.67 & 0.054 & 3.62 & 0.161 & 0.012 & 0.826 \\
\hline
\end{tabular}

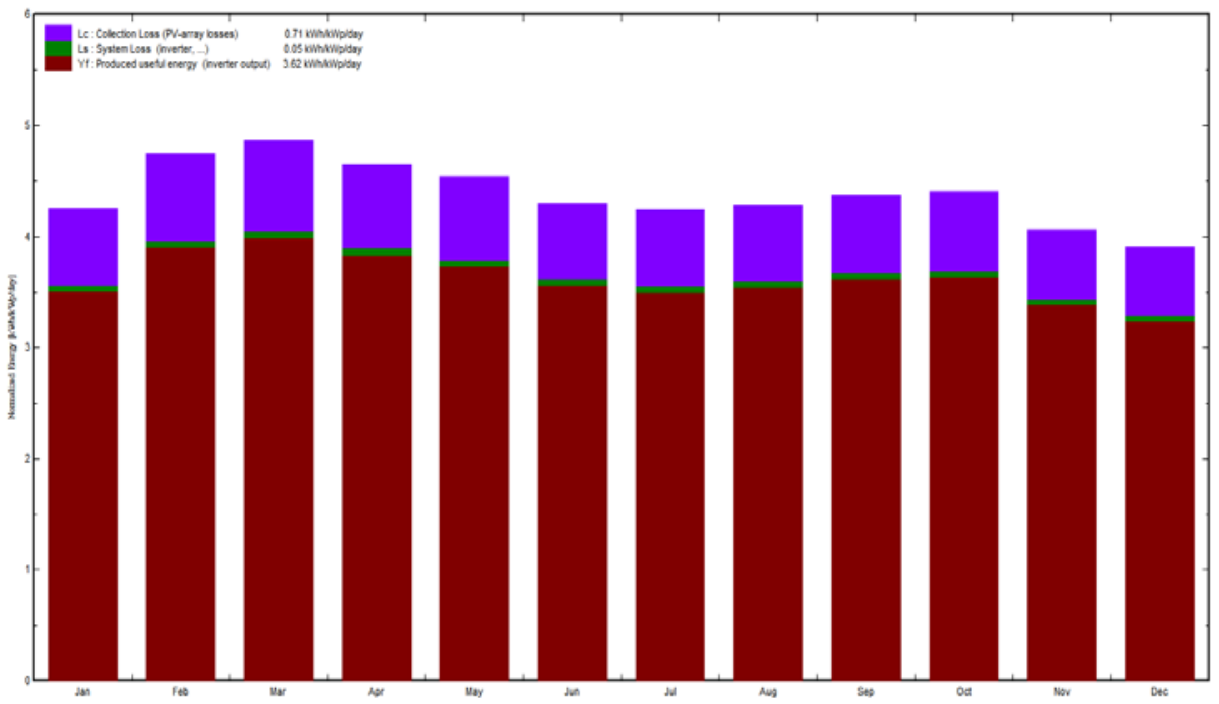

Fig.3. Normalized productions (per installed kWp): nominal power $280 \mathrm{kWp}$ 


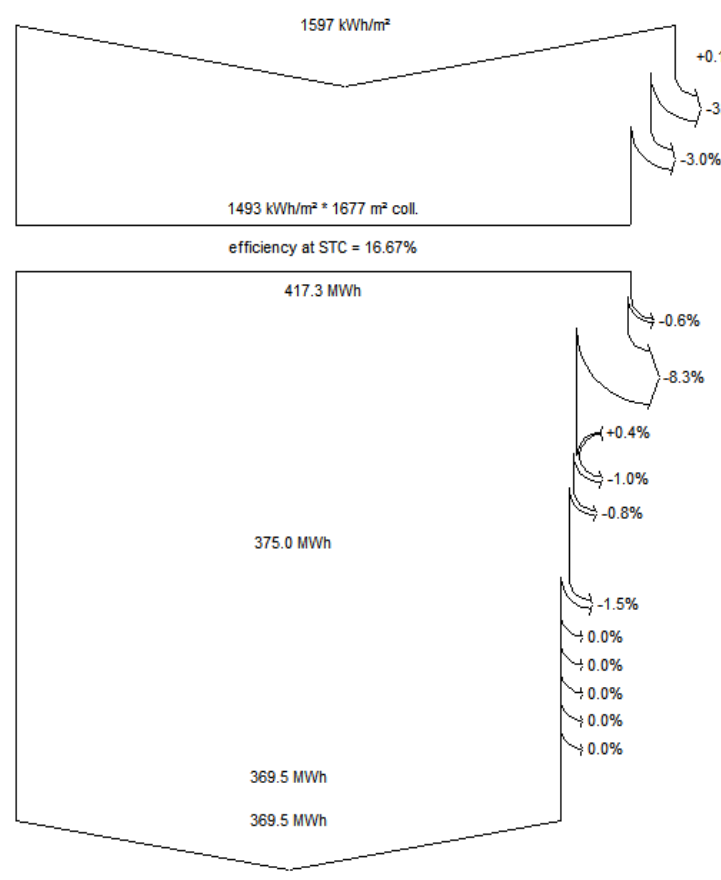

Horizontal global irradiation

Global incident in coll. plane

LAM factor on global

Soiling loss factor

Effective irradiance on collectors

PV conversion

Array nominal energy (at STC effic.)

- PV loss due to irradiance level

PV loss due to temperature

Module quality loss

Module array mismatch loss

Ohmic wiring loss

Array virtual energy at MPP

- Inverter Loss during operation (efficiency)

Inverter Loss over nominal inv. power

Inverter Loss due to power threshold

Inverter Loss over nominal inv. voltage Inverter Loss due to voltage threshold

Night consumption

Available Energy at Inverter Output

Energy injected into grid

Fig.4. Overall System loss flow chart

Daily Input Output diagram

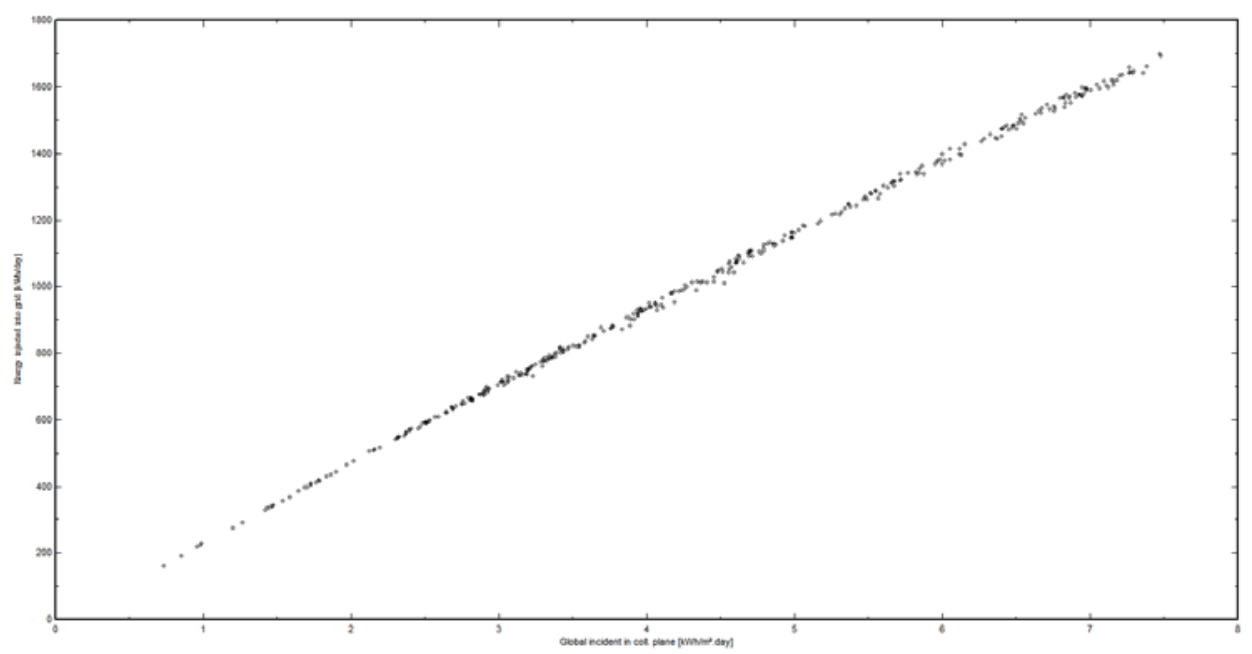

Fig.5. Daily Input / Output curve 


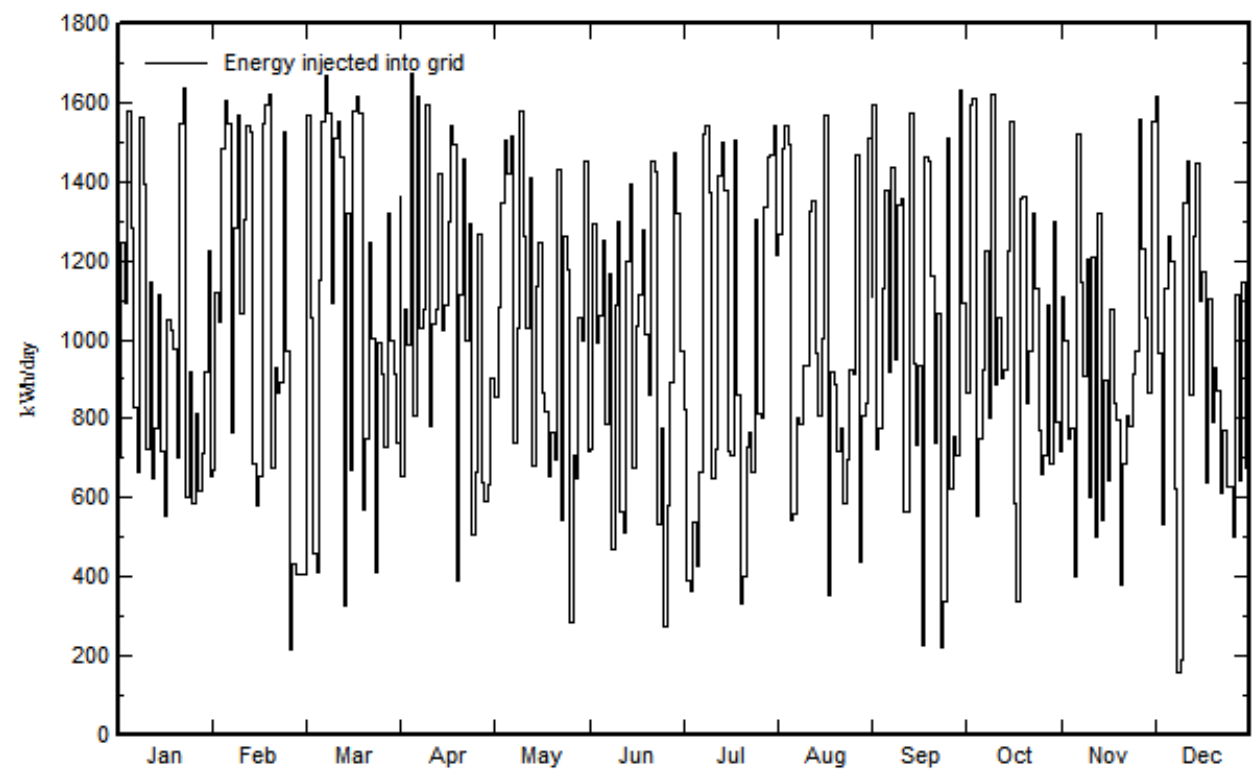

Fig.6. Energy injected into the grid

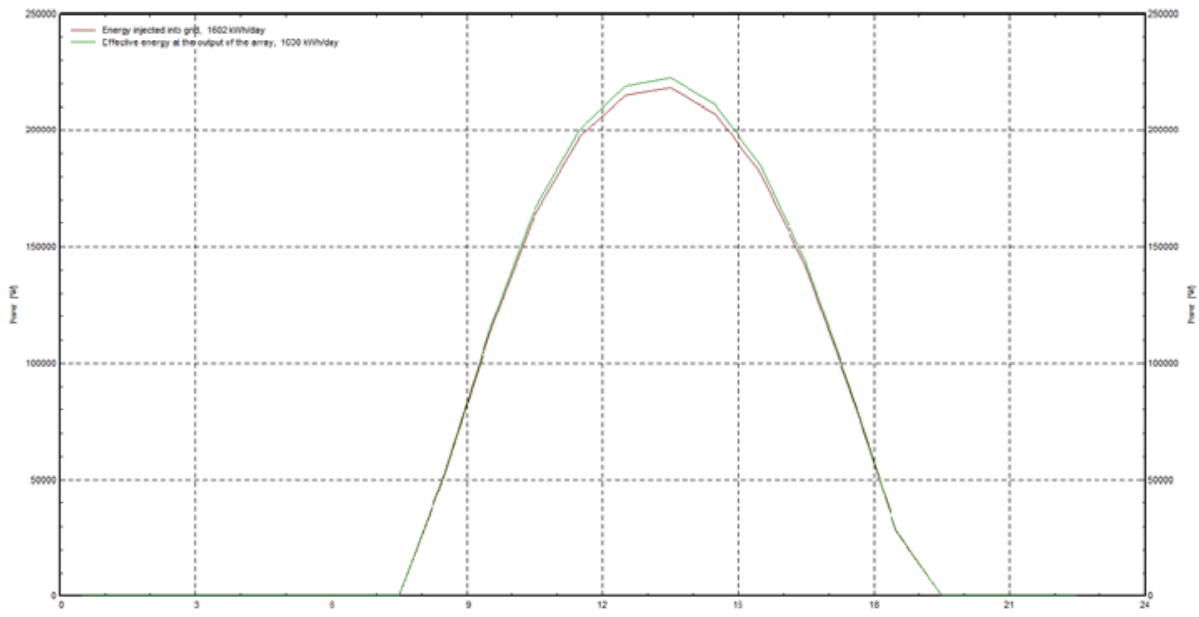

Fig.7. Comparisons of energy injected to the grid and effective energy at the output of the array

\section{Economic Analysis}

Economic analysis for the solar carport is carried out in PVsyst for the PV modules, structures, inverters, and all accessories. All the rates are considered in MYR as all the core modules of the system is readily available in Malaysia. The central core modules of the system or high cost are occurring for the PV modules and inverters. Each solar panel is considered for 1153.37 MYR and inverters are considered for 13,472 MYR, complete wiring is considered as 147,350 MYR and support structures 345.98 MYR. Generally, 30\% of the system cost is allotted for the structures along with the prices the nominal taxes are 6 
$\%$ without considering any subsidies. The total investment required to install $280 \mathrm{kWp}$ solar carport is 1616650.41 MYR. Annuities and yearly maintenance cost of 213,573.62 MYR. Availing Project loan for the entire project at a $5 \%$ rate of interest for ten years with $12.95 \% \mathrm{CAP} /$ year can produce energy for $0.58 \mathrm{MYR} / \mathrm{kWh}$.

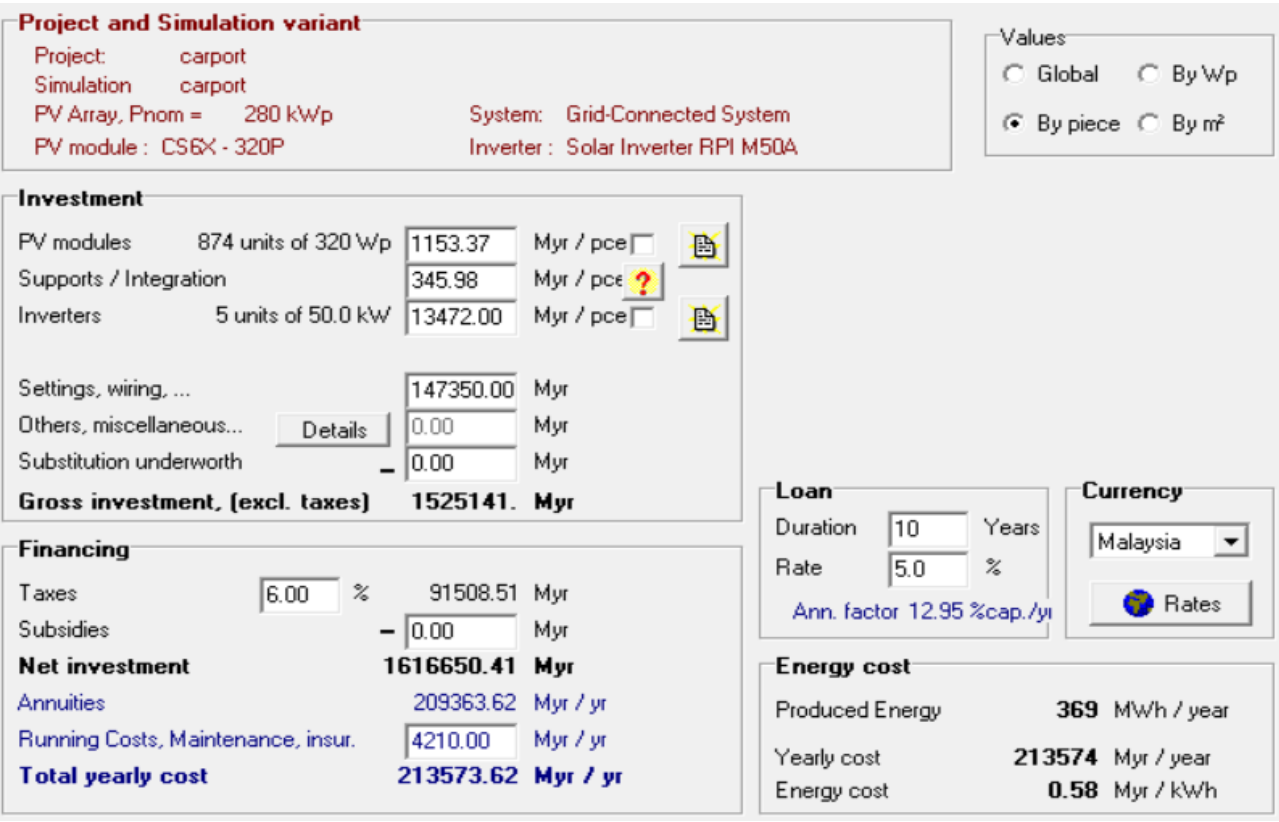

Fig.8. Economic evaluation of the proposed system

Tarification Strategy
$\lceil$ Hourly tariff variations
$\varpi$ Peak tariff defined
$\lceil$ Seasonal tariff variations
$\lceil$ Net metering

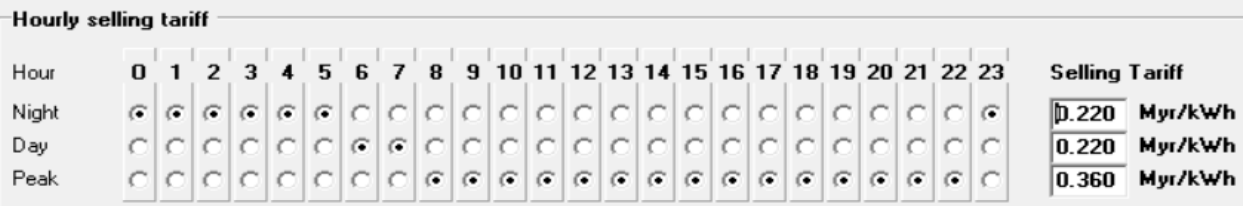

\section{Other General parameter}

Annual Connexion Tax $\quad 0.000$ Myr Annual Tariff depreciation $2.0 \div \%$ year Annual production reduction $2.0 \div$ \%/year Duration of tariff warranty $20 \div$ years Selling tariff drop after warranty $\sqrt{10 \div \div \%}$

This analysis should appear on printed report

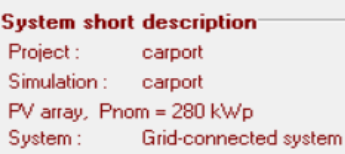




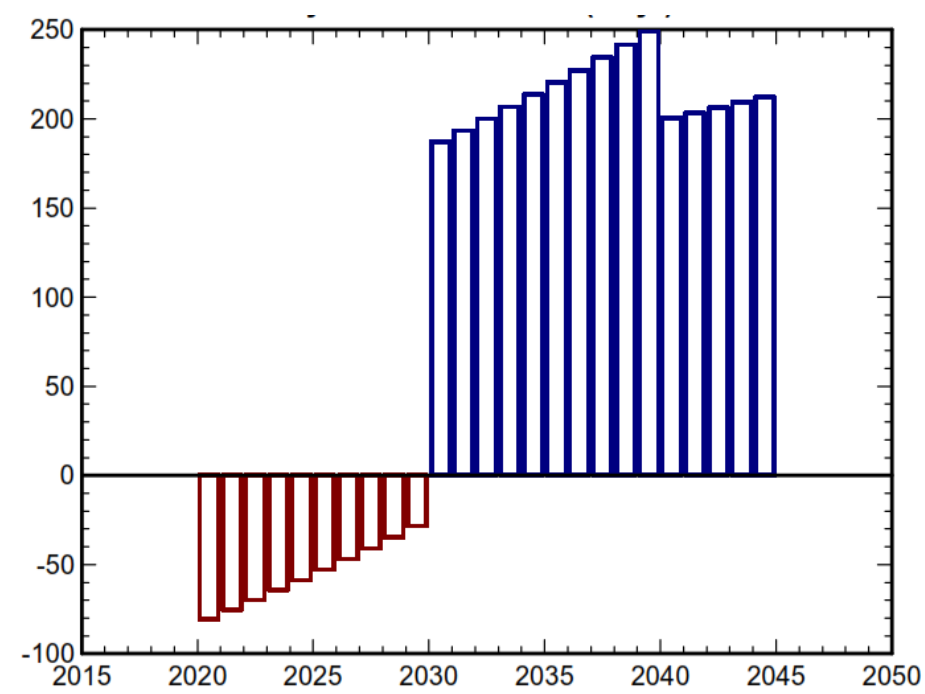

Fig. 10. yearly financial balance (kMyr)

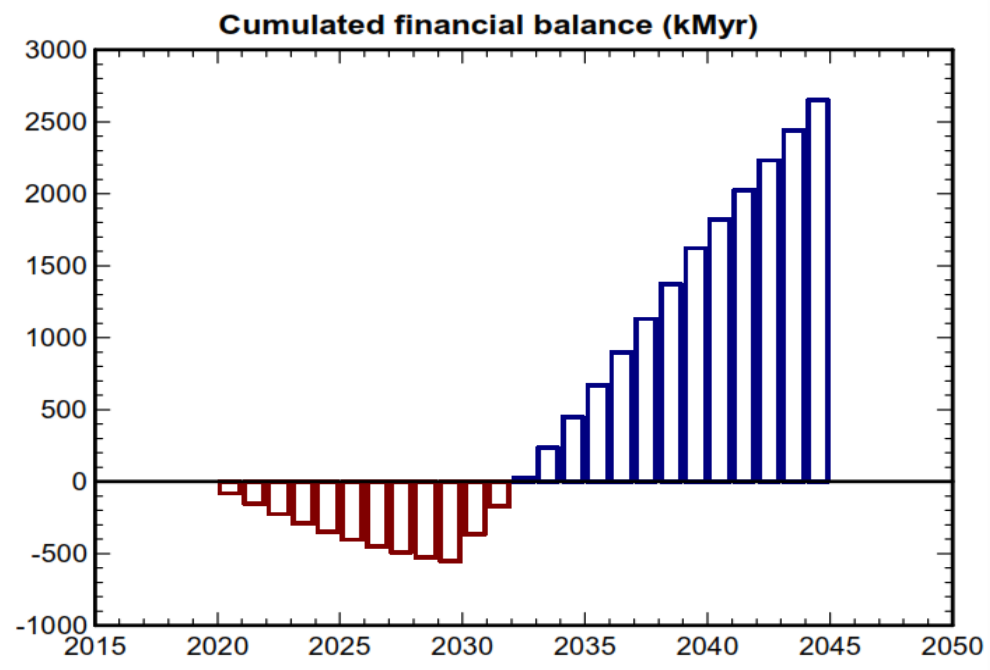

Fig.11. Cumulated financial balance (kMYR)

Based on the simulation Figure 8, Figure 9, Figure 10, and Figure 11 calculation performed for the solar carport are designated for 25 years of fully functioning plant by [31] hourly selling tariff of $0.220 \mathrm{MYR} / \mathrm{kWh}$ from $2300 \mathrm{hrs}$ to $0700 \mathrm{hrs}$ and $0.360 \mathrm{MYR} / \mathrm{kWh}$ from $0800 \mathrm{hrs}$ to $2200 \mathrm{hrs}$ along with $2 \%$ tariff depreciation per year and by assuming $10 \%$ tariff drop after 20 years, will get the payback from the year 2032 which is given in table 2 . At the project period of the $24^{\text {th }}$ year, the cumulative balance of $2,653.6 \mathrm{kMYR}$ will be the profit only the energy generated from the Solar carport. Additionally, the energy generated can be sold to EV drivers at the respective prices decided by the government or the plant proprietor to make additional profits. During this entire process, the amount of $\mathrm{CO}_{2}$ emissions reduced will be 4,890 tons. 
Table 2. Long term economic balance (kMYR)

\begin{tabular}{|c|c|c|c|c|c|c|}
\hline SI.No & Year & $\begin{array}{c}\text { Loan @ } \\
\mathbf{5 . 0 \%}\end{array}$ & $\begin{array}{c}\text { Running } \\
\text { costs }\end{array}$ & $\begin{array}{c}\text { Energy } \\
\text { sold }\end{array}$ & $\begin{array}{c}\text { Yearly } \\
\text { balance }\end{array}$ & $\begin{array}{c}\text { Cumulative } \\
\text { balance }\end{array}$ \\
\hline 1 & 2020 & 209.4 & 4.2 & 132.9 & -80.7 & -80.7 \\
\hline 2 & 2021 & 209.4 & 4.2 & 138.3 & -75.3 & -155.9 \\
\hline 3 & 2022 & 209.4 & 4.2 & 143.8 & -69.8 & -225.8 \\
\hline 4 & 2023 & 209.4 & 4.2 & 149.3 & -64.2 & -290.0 \\
\hline 5 & 2024 & 209.4 & 4.2 & 155.0 & -58.5 & -348.5 \\
\hline 6 & 2025 & 209.4 & 4.2 & 160.8 & -52.7 & -401.3 \\
\hline 7 & 2026 & 209.4 & 4.2 & 166.7 & -46.8 & -448.1 \\
\hline 8 & 2027 & 209.4 & 4.2 & 172.7 & -40.8 & -489.0 \\
\hline 9 & 2028 & 209.4 & 4.2 & 178.8 & -34.7 & -523.7 \\
\hline 10 & 2029 & 209.4 & 4.2 & 185.1 & -28.5 & -552.2 \\
\hline 11 & 2030 & 0.0 & 4.2 & 191.4 & 187.2 & -365.0 \\
\hline 12 & 2031 & 0.0 & 4.2 & 197.8 & 193.6 & -171.4 \\
\hline 13 & 2032 & 0.0 & 4.2 & 204.4 & 200.2 & 28.8 \\
\hline 14 & 2033 & 0.0 & 4.2 & 211.0 & 206.8 & 235.6 \\
\hline 15 & 2034 & 0.0 & 4.2 & 217.8 & 213.6 & 449.1 \\
\hline 16 & 2035 & 0.0 & 4.2 & 224.6 & 220.4 & 669.6 \\
\hline 17 & 2036 & 0.0 & 4.2 & 231.6 & 227.4 & 896.9 \\
\hline 18 & 2037 & 0.0 & 4.2 & 238.7 & 234.5 & 1131.4 \\
\hline 19 & 2038 & 0.0 & 4.2 & 245.8 & 241.6 & 1373.0 \\
\hline 20 & 2039 & 0.0 & 4.2 & 253.1 & 248.9 & 1621.9 \\
\hline 21 & 2040 & 0.0 & 4.2 & 204.7 & 200.5 & 1822.4 \\
\hline 22 & 2041 & 0.0 & 4.2 & 207.6 & 203.4 & 2025.8 \\
\hline 23 & 2042 & 0.0 & 4.2 & 210.5 & 206.3 & 2232.1 \\
\hline 24 & 2043 & 0.0 & 4.2 & 213.5 & 209.3 & 2441.4 \\
\hline 25 & 2044 & 0.0 & 4.2 & 216.4 & 212.2 & 2653.6 \\
\hline & & & & & & \\
\hline
\end{tabular}

\section{Discussion on Analysis}

The virtual study carried at simulation level for the mentioned location at Taylor's University shows that System and economic analysis shows that the PEVCS is suitable sustainable EV charging Station with less carbon emissions and great revenue generator. Most of the PEVCS are designed based on the distance to drive per day which is the primary criteria to install Solar PV in home and condominiums. But, as a distributed energy resource and as a virtual power plant the proposed virtual study will be a stand-alone application for work place CS. Earlier most of the solar carport are not intend for EV charging rather they are used for insight solar power generation to cater the local load demand. Whereas now the solar car port can be integrated with EV chargers to charge EVs. So, this virtual study in Taylor's University can be considered as feasibility study for future implementation. As per the analysis without any government subsidy Taylor's university can sell power at 0.58 MYR for both power generation and as well as charging session. The main limitation of this study is based on the availability of solar panels, Inverters and EV chargers as the main design is considered with predefined solar modules and inverters in the software. Despite of these limitation the analysis can considered for the implementation of the PEVCS. 


\section{Conclusion}

PEVCS is designed which is quite common structure for most of the PEVCS. So, the system and economic analysis carried out is applicable for most of the general feasibility studies. In this paper, system and economic analysis is carried out for 25 years where the payback period will be of 12 years. The generated energy from solar PV will be either used to charge EVs or it can give back to TNB at $0.58 \mathrm{MYR} / \mathrm{kWh}$ and reduce 4,890 tons $\mathrm{CO}_{2}$ emissions. Since Malaysia is lacking in charging station infrastructure, there is a need for different feasibility studies and virtual case studies for PEVCS. By choosing appropriate methodology and tools various organisations and institutions can accommodate PEVCS with full utilisation of generated power. PEVCS can also make to consume less energy from the grid (TNB). As solar PV and EV are both in budding stages of development in Malaysia, this work can act as a suitable reference. Further as per the program, Feed-in Tariff (FiT) [31] TNB will provide a fixed price for energy produced and exported to the grid once if the virtual study becomes real time case study. From the above analysis it is feasible for Taylor's University to apply this new methodology to become sustainable university.

Acknowledgements: This work was supported by Taylor's University through its TAYLOR'S PhD SCHOLARSHIP Programme through grant TUFR/2017/001/01.

\section{Reference:}

1. H. Mehrjerdi and E. Rakhshani, J. Clean. Prod., 229, 463-469 (2019)

2. J. Zhang, C. Liu, R. Yuan, T. Li, K. Li, B. Li, J. Li, and Z. Jiang, Glob. Energy Interconnect., 2, 150-159 (2019)

3. N. Wang, L. Tang, and H. Pan, Technol. Forecast. Soc. Change, 126, 284-291 (2018)

4. H. A. Bonges III and A. C. Lusk, Transp. Res. Part A Policy Pract., 83, 63-73 (2016)

5. H. Mehrjerdi, Int. J. Hydrogen Energy, 44, 11574-11583 (2019)

6. F. Kley, C. Lerch, and D. Dallinger, Energy Policy, 39, 3392-3403 (2011)

7. C. Munnings, "Solar -powered electric vehicle charging," (2019) [Online]. Available:https://www.csiro.au/en/Research/EF/Areas/Grids-and-storage/Intelligentsystems/Solar-charging. [Accessed: 14-Oct-2020].

8. F. G. Becker, "PV for your EV: Solar tech powers electric cars through summer," (2019) [Online]. Available: https://www.csiro.au/en/News/News-releases/2019/PVfor-your-EV-solar-tech-powers-electric-cars-through-summer. [Accessed: 14-Oct2020].

9. L. Wang, "Beautiful, solar-powered EV charging stations promise to charge a vehicle in 15 minutes," (2019) [Online]. Available: https://inhabitat.com/beautiful-solarpowered-ev-charging-stations-promise-to-charge-a-vehicle-in-15-minutes/. [Accessed: 14-Oct-2020].

10. J. A. Domínguez-Navarro, R. Dufo-López, J. M. Yusta-Loyo, J. S. Artal-Sevil, and J. L. Bernal-Agustín, Int. J. Electr. Power Energy Syst., 105, 46-58 (2019)

11. Y. Zhang, Y. He, X. Wang, Y. Wang, C. Fang, H. Xue, and C. Fang, Glob. Energy Interconnect., 1.2, 145-152 (2019)

12. G. Rajendran, C. A. Vaithilingam, K. Naidu, and K. S. P. Oruganti, SN Appl. Sci., 2, $1-15$ (2020)

13. Y. Kobayashi, N. Kiyama, H. Aoshima, and M. Kashiyama, 2011 IEEE intelligent vehicles symposium (IV), 920-925 (2011)

14. J. Lee and G.-L. Park, Neurocomputing, 148, 181-186 (2015)

15. F. Locment, M. Sechilariu, and C. Forgez, 2010 IEEE Vehicle Power and Propulsion 
Conference, 1-6 (2010)

16. S. Lukic, P. Mulhall, and A. Emadi, J. Asian Electr. Veh., 6, 1135-1143 (2008)

17. A. Mohamed, V. Salehi, T. Ma, and O. Mohammed, IEEE Trans. Sustain. Energy, 5, 577-586 (2013)

18. Q. Chen, N. Liu, C. Wang, and J. Zhang, 2014 IEEE Conference and Expo Transportation Electrification Asia-Pacific (ITEC Asia-Pacific), 1-6 (2014)

19. K. Satya Prakash Oruganti, C. Aravind Vaithilingam, G. Rajendran, and R. A, Energies, 12, 18 (2019)

20. I. S. Bayram, G. Michailidis, M. Devetsikiotis, S. Bhattacharya, A. Chakrabortty, and F. Granelli, 2011 IEEE International Conference on Smart Grid Communications (SmartGridComm), 78-83 (2011)

21. Y. Guo, J. Hu, and W. Su, 2014 IEEE Transportation Electrification Conference and Expo (ITEC), 1-6 (2014)

22. J. Li, B. Yang, Y. Xu, C. Chen, X. Guan, and W. Zhang, Proceedings of the 33rd Chinese Control Conference, 7066-7071 (2014)

23. D. Miskovski and S. S. Williamson 2013 IEEE Transportation Electrification Conference and Expo (ITEC), 1-6 (2013)

24. Q. Chen, N. Liu, X. Lu, and J. Zhang 2014 IEEE Innovative Smart Grid Technologies-Asia (ISGT ASIA), 465-469 (2014)

25. P. Tulpule, V. Marano, S. Yurkovich, and G. Rizzoni, IEEE 2011 EnergyTech, 1-6 (2011)

26. W. Lee, L. Xiang, R. Schober, and V. W. S. Wong, 2013 IEEE International Conference on Smart Grid Communications (SmartGridComm), 145-150 (2013)

27. X. Li, L. A. C. Lopes, and S. S. Williamson, 2009 IEEE Power \& Energy Society General Meeting, 1-8 (2009)

28. Z. Rasin and M. F. Rahman, 2013 International Conference on Renewable Energy Research and Applications (ICRERA), 627-632 (2013)

29. H. Zhao and A. Burke, 2014 IEEE Int. Electr. Veh. Conf. IEVC 2014, 4-11 (2014)

30. R. J. Fosdick, "Electric Vehicle.," Automotive Industries AI, 1977. [Online]. Available:https://batteryuniversity.com/learn/article/electric_vehicle_ev. [Accessed: 14-Oct-2020].

31. SEDA, "Feed-in Tariff Rates for Solar PV," 2019. [Online]. Available: http://seda.gov.my/. [Accessed: 14-Oct-2020]. 